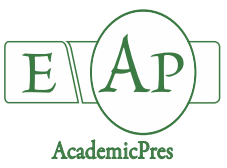

Estrada-Beltran A et al. (2020)

Notulae Botanicae Horti Agrobotanici Cluj-Napoca 48(2):862-870

DOI: $10.15835 /$ nbha 48211810

Research Article

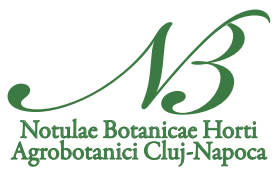

\title{
Effect of conventional and organic fertilizers on volatile compounds of raspberry fruit
}

\author{
Aztrid ESTRADA-BELTRAN ${ }^{1}$, Nora A. SALAS-SALAZAR ${ }^{1 *}$, \\ Rafael A. PARRA-QUEZADA ${ }^{1}$, Ana C. GONZALEZ-FRANCO ${ }^{1}$, \\ Mayra C. SOTO-CABALLERO ${ }^{1}$, Maria J. RODRIGUEZ-ROQUE ${ }^{1}$, \\ Maria A. FLORES-CORDOVA ${ }^{1}$, America CHAVEZ-MARTINEZ ${ }^{2}$ \\ ${ }^{1}$ Autonomous University of Chihuahua, Faculty of Agrotechnological Sciences, Pascual Orozco Avenue, Campus 1, Santo Niño, CP 31350, \\ Chihuahua,Mexico;nsalas@uach.mx(*correspondingauthor);aztrid_eb@hotmail.com;raparra@uach.mx; conzalez@uach.mx; \\ masoto@uach.mx;mjrodriguez@uach.mx;mafloresc@uach.mx \\ ${ }^{2}$ Autonomous University of Chibuahua, Faculty of Zootechnics and Ecology, Periferico Francisco R Almada, Km 1, CP 31453, \\ Chibuahua,México; amchavez@uach.mx
}

\begin{abstract}
Raspberries are widely consumed; the taste of these is determined by the interaction between sugars, organic acids and a set of volatile compounds. Meanwhile, organic agriculture has developed rapidly as an alternative to conventional system, and has been driven by the demand for pesticide-free food that brings greater benefits to human health. However, this system can alter the integral quality of the fruit, including the aroma, which has been little studied. Therefore, the objective of this study was to evaluate the effect of the application of organic and conventional fertilizers, in the presence of volatile compounds synthesized in the cr. 'Heritage' raspberry, during two crop cycles. The qualitative profile of volatile compounds was analysed by mass gas chromatography, obtaining as a result that fertilization treatments significantly affected the emission of volatile compounds in the most abundant functional group (C13 norisoprenoids) 48.5 vs. $25.8 \%$ and 56.9 vs. $29.1 \%$ in conventional and organic, in 2017 and 2018, respectively ( $\mathrm{p} \leq 0.05)$. The crop cycle affected the concentration of aldehydes (11.2 vs. 30.6\% in organic, in 2017 and 2018, respectively ( $p \leq 0.05$ ). Impact compounds such as $\alpha$-ionone (13.92 vs. $9.08 \%$ and 25.34 vs. $9.17 \%$ in conventional and organic in 2017 and 2018 , respectively) and $\beta$-ionone ( 24.93 vs. $14.10 \%$ and 22.66 vs. $15.94 \%$ in conventional and organic in 2017 and 2018, respectively), presented greater abundance in conventional fertilization $(\mathrm{p} \leq 0.05)$. Since there were changes in the volatile compounds, it is recommended to study whether the consumer perceives these changes.
\end{abstract}

Keywords: agricultural; quality; Rubus idaeus L.; season; taste

\section{Introduction}

Raspberry (Rubus idaeus L.) is a perennial crop, a member of the Rosaceae family that produces a red fruit with a sweet and sour taste at the same time (Aprea et al., 2015). Raspberry production in Mexico for 2018 
exceeded 130,000 tons. The main producing states are Jalisco (71\%), Baja California (10\%), Michoacán (18\%) (SIAP, 2018). The most important raspberry varieties in México are 'Autumn Bliss', 'Summit' and 'Heritage', which is originally from the United States (Guzman et al., 2004).

These types of raspberries are widely consumed due to their benefits in human health; since they contain a wide variety of phytochemicals that help to prevent chronic diseases (Rao and Snyder, 2010), although they are also appreciated for their characteristic flavour. The taste of raspberry is determined by the interaction between sugars, organic acids and a set of approximately 300 volatile compounds (Aprea $e$ t al., 2015).

Volatile compounds participate in the development of aroma, which is often used by the consumer as an indicator of quality, maturity and freshness. Likewise, the lacks of aroma or unpleasant aromas are indicators of deterioration, decomposition, lack of maturity and, in general, poor quality (Forney, 2001).

Volatile compounds reported in raspberries include esters, aldehydes, alcohols, ketones, monoterpenes, C-13 norisoprenoids (Aprea et al., 2009; Aprea et al., 2015). Highlighting the compounds: $\alpha$ - and $\beta$-ionones, $\alpha$-ionol, $\beta$-damascenone, linalool, geraniol, (Z)-3-hexenol, benzyl alcohol, acetoin, raspberry ketone, acetic acid and hexanoic acid (Larsen et al., 1991). The synthesis of these compounds is affected by several factors, including the genetic composition of the fruit, its maturity, and environmental conditions during its cultivation, handling in the harvest and storage (Forney, 2001).

In raspberry, as in other crops, there are two production alternatives: conventional and organic, the first guarantees high yield and quality, but requires extensive use of chemical fertilizers, which are important, but create environmental problems; therefore, there has been a resurgence of interest in agricultural practices that are environmentally friendly and sustainable, such as organic production (Esitken et al., 2005). Organic agriculture has developed rapidly as an alternative to conventional system, and has been driven by the demand for pesticide-free foods that provide greater benefits for human health (Gomiero, 2017). In addition to the above, organic farming systems have proven been capable of producing food with high quality standards (Lairon, 2010) and higher phytochemical content (Frias et al., 2019). It has been proved that the type of fertilization used has an impact on the nutritional components of fruits, these being greater in fruits fertilized with organic fertilizers (Benbrook, 2009). However, to date, little or no importance has been given to the impact of type fertilization on the concentration of volatile compounds in fruits, specifically on raspberry fruit. In a study conducted on the effects of the application of different fertilizers, organic and conventional, on the volatile compounds of 'Golden Delicious' apples were investigated, finding that the type of fertilization significantly affected the level of compounds related to flavour, although few of these responses were consistent during the two years of harvest in which the study was carried out. Even when the treatments resulted in marked differences in the level of mineral nitrogen in the soil, this was reflected in a limited impact on the flavourrelated compounds in the fruit, the strongest effect being a 45\% change in the level of C6 aldehydes (Raffo et al., 2014).

Despite, the economic and nutritional importance of raspberry, there is limited information previously published related to the effect of conventional and organic fertilizers on volatile compounds present on this fruit. Therefore, the objective of this study was to evaluate the effect of the application of organic and conventional fertilization on emissions of volatile compounds in raspberry cv 'Hertiage', during two consecutive agronomic cycles.

\section{Materials and Methods}

\section{Biological material}

The work was carried out at the Faculty of Agrotechnological Sciences of the Autonomous University of Chihuahua, Cuauhtémoc campus, located at $28^{\circ} 24^{\prime} 45.1^{\prime \prime} \mathrm{N}, 106^{\circ} 52^{\prime} 54.9^{\prime \prime} \mathrm{W}$ and at 2060 meters above sea level. The climate is mild with minimum temperatures of $-16^{\circ} \mathrm{C}$ in winter and maximum temperatures in 
summer of $38^{\circ} \mathrm{C}$, with an annual rainfall of $499.3 \mathrm{~mm}$ (Table 1). The soil is clay-loam texture. The raspberry plantation was established with the autumn-producing 'Heritage' variety, in February 2015 with bare roots.

Table 1. Weather conditions

\begin{tabular}{|c|c|c|c|c|c|c|c|c|}
\hline \multirow{2}{*}{ Month } & \multicolumn{4}{|c|}{2017} & \multicolumn{4}{c|}{2018} \\
\cline { 2 - 10 } & Min & Max & Pres & Rad solar & Min & Max & Pres & Rad solar \\
\cline { 2 - 9 } & $\left({ }^{\circ} \mathrm{C}\right)$ & $\left({ }^{\circ} \mathrm{C}\right)$ & $(\mathrm{mm})$ & $\mathrm{Kw} \mathrm{m}{ }^{-2}$ & $\left({ }^{\circ} \mathrm{C}\right)$ & $\left({ }^{\circ} \mathrm{C}\right)$ & $(\mathrm{mm})$ & $\mathrm{Kw} \mathrm{m}^{-2}$ \\
\hline January & -0.9 & 17.0 & 2.5 & 0.16 & -2.6 & 16.7 & 0.0 & 0.17 \\
\hline February & 0.3 & 19.8 & 0.4 & 0.20 & 2.9 & 18.2 & 3.6 & 0.17 \\
\hline March & 4.0 & 23.1 & 0.6 & 0.25 & 3.5 & 22.1 & 1.7 & 0.24 \\
\hline April & 6.3 & 25.6 & 1.9 & 0.31 & 6.8 & 25.1 & 0.4 & 0.31 \\
\hline May & 7.7 & 27.4 & 4.5 & 0.35 & 8.8 & 28.9 & 5.9 & 0.33 \\
\hline June & 12.5 & 31.0 & 11.1 & 0.32 & 13.6 & 30.4 & 20.5 & 0.30 \\
\hline July & 13.6 & 25.6 & 288.0 & 0.23 & 13.8 & 27.3 & 125.9 & 0.26 \\
\hline August & 13.2 & 24.5 & 184.8 & 0.22 & 12.9 & 26.8 & 125.4 & 0.25 \\
\hline September & 10.3 & 25.1 & 38.7 & 0.23 & 10.8 & 24.3 & 89.5 & 0.21 \\
\hline October & 7.5 & 24.6 & 7.0 & 0.21 & 7.4 & 21.1 & 57.2 & 0.17 \\
\hline November & 4.5 & 24.3 & 0.0 & 0.16 & 0.0 & 18.5 & 3.90 & 0.17 \\
\hline December & 2.3 & 20.3 & 0.0 & 0.12 & -1.80 & 15.62 & 20.3 & 0.14 \\
\hline Total and average & 6.78 & 24.01 & 44.96 & 0.24 & 7.08 & 23.58 & 40.95 & 0.23 \\
\hline
\end{tabular}

\section{Experimental}

The experimental garden had 6 rows of 20 linear meters, with experimental units (UE) of 4 linear meters, with a distance between rows of $2 \mathrm{~m}$ and $1 \mathrm{~m}$ between each UE, with a density of 30 and 35 rods per linear $\mathrm{m}$. The distribution of the treatments was carried out at random, considering two treatments, one of conventional management and another organic, assigning the experimental units by agronomic management.

\section{Crop management}

The organic management consisted of applying vermicompost, leaching of vermicompost and commercial organic fertilizer. The physicochemical properties of vermicompost, leaching of vermicompost and commercial fertilizer are indicated in Table 2. The compost was applied at a rate of $15 \mathrm{t} \mathrm{ha}^{-1}$ for the two years of study (2017 and 2018). The vermicompost leaching was applied in the order of a rate of $24 \mathrm{~m}^{3} \mathrm{ha}^{-1}$. Before applying the vermicompost leaching, it's $\mathrm{pH}$ was lowered from 8.2 to 7 , with organic apple vinegar. Finally, a commercial organic fertilizer $7.5 \mathrm{t} \mathrm{ha}^{-1}$ was also applied (Table 3). Fertilizer applications starter in May in both crop cycles and continued weekly until September (16 and 9 applications, respectively).

In conventional crops, commercial (synthetic) fertilizers of nitrogen, phosphorus and potassium (NPK) were applied, which were based on ammonium nitrate, triple 17 and potassium sulfate. The nitrogen inorganic fertilizer was applied at a rate of $150 \mathrm{~kg} \mathrm{ha}^{-1}$ from May to October for 2017 and 2018. The nitrogen rates remained the same during the two years to promote reproductive growth. Inorganic fertilizers of $\mathrm{P}$ were also added at a rate of $40 \mathrm{~kg} \mathrm{ha}^{-1}$ and $190 \mathrm{~kg} \mathrm{ha}^{-1}$ of K, according to the recommendation of Parra et al. (2008) (Table 4).

The irrigation system was drip with an expense of $2 \mathrm{l} \mathrm{hr}^{-1}$ per dropper. With this system, it was watered three times a week, lasting five hours. Weed control was carried manually. The weather condition to which the raspberry crop was exposed in the two years of study is shown in Table 1.

\section{Harvest}

The harvest was done manually, two partial crops per week during the 2017 production cycle, beginning and mid-June. For 2018, start in the first week of July. The raspberries were harvested once they could be 
detached from the receptacle and had an intense red colour (ripening grade 3) (Peña et al., 2006). The fruits were randomly selected within the experimental unit and subsequently taken to the laboratory for analysis.

Table 2. Chemical and physical characteristics of vermicompost, leaching of vermicompost and commercial fertilizer

\begin{tabular}{|c|c|c|c|}
\hline Parameter & Vermicompost & $\begin{array}{c}\text { Leaching of } \\
\text { vermicompost }\end{array}$ & $\begin{array}{c}\text { Commercial organic } \\
\text { fertilizer }\end{array}$ \\
\hline $\mathrm{pH}$ & 6 & 8.2 & 6.7 \\
\hline Organic material (\%) & 85 & 40 & 45 \\
\hline Total organic carbon (\%) & 18.57 & - & - \\
\hline $\mathrm{N}$ total (\%) & 2.24 & 2.3 & 4 \\
\hline P total (\%) & 0.12 & 0.3 & 4 \\
\hline K total (\%) & 0.01 & 0.37 & 16 \\
\hline Ca total (\%) & 1.33 & 0.01 & 1.6 \\
\hline Mg total (\%) & 1.21 & 1 & 4 \\
\hline
\end{tabular}

Table 3. Organic fertilizers applied by production season

\begin{tabular}{|c|c|c|}
\hline Organic fertilizers & 2017 & 2018 \\
\hline Vermicompost & $15 \mathrm{t} \mathrm{ha}^{-1}$ & $15 \mathrm{t} \mathrm{ha}^{-1}$ \\
\hline Leaching of vermicompost & $24 \mathrm{~m}^{3} \mathrm{ha}^{-1}$ & $24 \mathrm{~m}^{3} \mathrm{ha}^{-1}$ \\
\hline Commercial organic fertilizer & $7.5 \mathrm{t} \mathrm{ha}^{-1}$ & $7.5 \mathrm{t} \mathrm{ha}^{-1}$ \\
\hline
\end{tabular}

Table 4. Chemical fertilizers applied by production season

\begin{tabular}{|c|c|c|}
\hline Conventional fertilizers & 2017 & 2018 \\
\hline$\left(\mathrm{NH}_{4}\right)_{2} \mathrm{HPO}_{4}$ & $315 \mathrm{~kg} \mathrm{ha}^{-1}$ & $315 \mathrm{~kg} \mathrm{ha}^{-1}$ \\
\hline $\mathrm{K}_{2} \mathrm{SO}_{4}$ & $40 \mathrm{~kg} \mathrm{ha}^{-1}$ & $40 \mathrm{~kg} \mathrm{ha}^{-1}$ \\
\hline$\left(\mathrm{NH}_{4}\right)_{2} \mathrm{SO}_{4}$ & $284 \mathrm{~kg} \mathrm{ha}^{-1}$ & $284 \mathrm{~kg} \mathrm{ha}^{-1}$ \\
\hline
\end{tabular}

\section{Sample preparation}

Fifteen raspberry fruits per treatment were macerated manually, in a porcelain mortar, until a homogeneous mixture was obtained. $20 \mathrm{ml}$ of juice were taken and placed in $20 \mathrm{ml}$ PTFE vials and stored at $80{ }^{\circ} \mathrm{C}$ until analysis.

\section{Volatile compounds}

The concentration of volatile compounds was determined by gas chromatography coupled to mass spectrometry, using the solid phase microextraction technique (SPME). A $2 \mathrm{ml}$ aliquot of thawed juice was taken in a thermobath (Felisa), it was placed in $4 \mathrm{ml}$ vials with $0.65 \mathrm{~g}$ of sodium chloride and kept under stirring while the SPME fiber (65 $\mathrm{m}$, PDMS-DVB, Agilent USA) was exposed to the sample head space, for $60 \mathrm{~min}$, at room temperature. The fibre was desorbed in the injection port for $5 \mathrm{~min}$ at $200{ }^{\circ} \mathrm{C}$ within the GC-MS (Agilent) system, equipped with a DB-WAX column $(60 \mathrm{~m} \times 0.25 \mathrm{~mm}, 0.25 \mu \mathrm{m}$, Agilent USA). The chromatographic conditions were as follows: injector temperature of $200{ }^{\circ} \mathrm{C}$, initial oven temperature of $33^{\circ} \mathrm{C}$ sustained for $5 \mathrm{~min}$, increasing to $50{ }^{\circ} \mathrm{C}$ at $2{ }^{\circ} \mathrm{C} \mathrm{min} \mathrm{min}^{-1}$, increasing the temperature again to $250{ }^{\circ} \mathrm{C}$ at a rate of 5 ${ }^{\circ} \mathrm{C} \mathrm{min}{ }^{-1}$, holding it for $6.5 \mathrm{~min}$. Helium was used as a carrier gas with a linear velocity of $30 \mathrm{~cm} \mathrm{~s}^{-1}$. Mass spectra were obtained by electronic ionization at $70 \mathrm{eV}$. The temperatures of the transfer line and the ion trap were 250 and $180{ }^{\circ} \mathrm{C}$, respectively. The identification of volatile compounds was made by comparing the mass spectra obtained from the samples against those reported in the NIST MS 2014 library. All values represent the average of triplicated sampled. The results were expressed in relative concentration as the ratio of the area of the base peak of the compound to the total area of all the compounds. 


\section{Statistical procedures}

Likewise, an analysis of variance (one-way ANOVA) and multiple comparison of Tukey means $(p \leq$ 0.05 ) was performed using the statistical program Minitab version 16 (Statistical Software, USA).

\section{Results and Discussion}

\section{Volatile compounds}

Volatile compounds identified in raspberry fruits grown with conventional and organic management during two years of study are shown in Table 5. Seven alcohols, five C13-norisoprenoids, five monoterpenes, three aldehydes, three ketones, three acids and two esters were identified. It was observed that the determinations of most volatile compounds in raspberries were influenced by fertilization and / or seasonal variation.

Table 5. Relative concentrations of volatile compounds in raspberry fruit (Rubus idaeus L.)

\begin{tabular}{|c|c|c|c|c|c|c|}
\hline \multirow{2}{*}{\multicolumn{3}{|c|}{ Parameter }} & \multicolumn{2}{|c|}{2017} & \multicolumn{2}{|c|}{2018} \\
\hline & & & \multicolumn{4}{|c|}{ Fertilizer } \\
\hline $\operatorname{Rt}(\min )$ & Compound & $\begin{array}{c}\text { Diagnostic ions } \\
(\mathrm{m} / \mathrm{z})\end{array}$ & Conventional & Organic & Conventional & Organic \\
\hline 7.81 & Ethyl acetate & $\begin{array}{c}\text { (43) } 999(61) 153 \\
(45) 146(29) 124 \\
(70) 118\end{array}$ & $2.24 \pm 0.13 \mathrm{aA}$ & $11.93 \pm 5.76 \mathrm{aA}$ & $1.64 \pm 0.19 \mathrm{aA}$ & $5.48 \pm 0.10 \mathrm{bB}$ \\
\hline 10.05 & Ethanol & $\begin{array}{c}\text { (31) } 999(45) 514 \\
\text { (29) } 298(27) 224 \\
\text { (46) } 216\end{array}$ & $1.70 \pm 1.07 \mathrm{aA}$ & $2.05 \pm 0.18 \mathrm{aA}$ & $1.16 \pm 0.35 \mathrm{aA}$ & $4.58 \pm 0.82 \mathrm{bB}$ \\
\hline 15.18 & $\alpha$-Pinene & $\begin{array}{c}\text { (93) } 999(91) 454 \\
(92) 440(77) 358 \\
\text { (41) } 325\end{array}$ & $3.28 \pm 0.80 \mathrm{aA}$ & $4.11 \pm 0.31 \mathrm{a}$ & $1.15 \pm 0.36 \mathrm{~A}$ & n.d. \\
\hline 17.83 & Hexanal & $\begin{array}{c}\text { (56) } 999(44) 889 \\
(41) 810(57) 668 \\
(43) 569\end{array}$ & $2.49 \pm 1.25 \mathrm{aA}$ & $0.78 \pm 0.24 \mathrm{aA}$ & $2.67 \pm 0.30 \mathrm{aA}$ & $11.99 \pm 1.25 \mathrm{bB}$ \\
\hline 20.44 & 3-Hexenal & $\begin{array}{c}\text { (41) } 999(69) 516 \\
(55) 398(39) 352 \\
(42) 190\end{array}$ & $2.59 \pm 1.31 \mathrm{aA}$ & $8.06 \pm 2.28 \mathrm{aA}$ & $3.54 \pm 1.48 \mathrm{aA}$ & $7.14 \pm 1.75 b \mathrm{bB}$ \\
\hline 21.84 & $\alpha$-Phellandrene & $\begin{array}{c}(93) 999(91) 319 \\
(77) 307(92) 252 \\
(136) 173\end{array}$ & $2.00 \pm 0.71 \mathrm{aA}$ & $2.68 \pm 0.29 a$ & $1.34 \pm 0.16 \mathrm{~A}$ & n.d. \\
\hline 22.41 & 2-Heptanone & $\begin{array}{c}\text { (43) } 999(58) 601 \\
(71) 136(41) 110 \\
\text { (27) } 106\end{array}$ & $3.61 \pm 1.68 \mathrm{aA}$ & $7.22 \pm 0.09 \mathrm{aA}$ & $1.30 \pm 0.91 \mathrm{aA}$ & $1.83 \pm 0.22 \mathrm{aA}$ \\
\hline 23.27 & (E)-2-Hexenal & $\begin{array}{c}\text { (41) } 999(55) 942 \\
\text { (69) } 782(83) 668 \\
\text { (39) } 639\end{array}$ & $1.19 \pm 0.58 \mathrm{aA}$ & $2.60 \pm 0.02 \mathrm{aA}$ & $0.69 \pm 0.02 \mathrm{aA}$ & $11.83 \pm 0.13 \mathrm{bB}$ \\
\hline 23.55 & $\beta$-Phellandrene & $\begin{array}{c}\text { (93) } 999(77) 274 \\
(91) 274(136) 177 \\
\text { (79) } 168\end{array}$ & $1.47 \pm 0.60 \mathrm{~A}$ & n.d. & $0.68 \pm 0.02 \mathrm{~A}$ & n.d. \\
\hline 25.73 & Acetoin & $\begin{array}{c}(45) 999(43) 556 \\
(88) 99(27) 95(29) \\
55\end{array}$ & $2.98 \pm 0.90 \mathrm{a}$ & $1.90 \pm 0.20 \mathrm{aA}$ & n.d. & $0.26 \pm 0.01 \mathrm{~B}$ \\
\hline 26.40 & 3-Hexenyl acetate & $\begin{array}{c}\text { (43) } 999(67) 648 \\
(82) 374(41) 192 \\
\text { (39) } 130\end{array}$ & $2.74 \pm 1.05 \mathrm{aA}$ & $1.84 \pm 0.26 \mathrm{aA}$ & $0.86 \pm 0.14 \mathrm{aA}$ & $0.30 \pm 0.04 \mathrm{bB}$ \\
\hline 27.41 & 2-Heptanol & $\begin{array}{l}\text { (45) } 999(55) 292 \\
\text { (41) } 235(43) 224 \\
\text { (44) } 142\end{array}$ & $6.96 \pm 1.69 \mathrm{aA}$ & $6.01 \pm 0.36 \mathrm{aA}$ & $2.41 \pm 0.32 \mathrm{aA}$ & $2.34 \pm 0.13 \mathrm{aA}$ \\
\hline 28.42 & 1-Hexanol & $\begin{array}{l}\text { (56) } 999(43) 762 \\
\text { (31) } 571(55) 571 \\
\text { (41) } 570\end{array}$ & n.d. & n.d. & $1.43 \pm 0.12 \mathrm{a}$ & $0.53 \pm 0.05 b$ \\
\hline 28.73 & 3-Hexen-1-ol & $\begin{array}{l}\text { (41) } 999(67) 599 \\
\text { (39) } 390(55) 343 \\
\text { (82) } 282\end{array}$ & $2.62 \pm 0.64 \mathrm{~A}$ & n.d. & $2.60 \pm 0.05 \mathrm{aA}$ & $1.08 \pm 0.22 b$ \\
\hline 29.35 & 3-Hexen-1-ol, (Z) & $\begin{array}{l}(41) 999(67) 700 \\
(55) 351(39) 314 \\
(82) 303\end{array}$ & n.d. & $3.79 \pm 0.21$ & n.d. & n.d. \\
\hline
\end{tabular}


Estrada-Beltran A et al. (2020). Not Bot Horti Agrobo 48(2):862-870

\begin{tabular}{|c|c|c|c|c|c|c|}
\hline 30.68 & Acetic acid & $\begin{array}{c}(43) 999(45) 874 \\
(60) 570(15) 416 \\
(42) 137 \\
\end{array}$ & $2.55 \pm 1.60$ & n.d. & n.d. & n.d. \\
\hline 31.54 & 6-Methyl-5-hepten-2-ol & $\begin{array}{c}\text { (95) } 999(41) 778 \\
(45) 411(69) 408 \\
(67) 372 \\
\end{array}$ & $4.17 \pm 2.45 \mathrm{aA}$ & $2.18 \pm 1.80 \mathrm{aA}$ & $1.69 \pm 0.55 \mathrm{aA}$ & $0.31 \pm 0.05 \mathrm{aA}$ \\
\hline 33.73 & Linalool & $\begin{array}{c}\text { (71) } 999(93) 760 \\
(55) 637(43) 598 \\
(41) 564 \\
\end{array}$ & $1.68 \pm 0.72 \mathrm{aA}$ & $2.09 \pm 0.58 \mathrm{aA}$ & $0.60 \pm 0.07 \mathrm{aA}$ & $0.51 \pm 0.31 \mathrm{aA}$ \\
\hline 36.62 & Acetophenone & $\begin{array}{c}(105) 999(77) 858 \\
(51) 406(120) 327 \\
(43) 208\end{array}$ & $1.83 \pm 0.13 \mathrm{aA}$ & $1.84 \pm 0.59 \mathrm{aA}$ & $1.18 \pm 0.18 \mathrm{aB}$ & $0.60 \pm 0.06 \mathrm{bA}$ \\
\hline 36.95 & Ionone & $\begin{array}{c}(177) 999(43) 424 \\
(91) 176(135) 153 \\
(178) 133\end{array}$ & $24.93 \pm 1.34 \mathrm{aA}$ & $14.10 \pm 0.41 \mathrm{bA}$ & $22.66 \pm 3.21 \mathrm{aA}$ & $15.94 \pm 1.01 \mathrm{aA}$ \\
\hline 38.46 & Dihydro- $\alpha$-ionone & $\begin{array}{c}(43) 999(95) 690 \\
(136) 690(121) 600 \\
(41) 400\end{array}$ & $1.53 \pm 0.21 \mathrm{aA}$ & $0.70 \pm 0.40 \mathrm{aA}$ & $1.04 \pm 0.09 \mathrm{aA}$ & $0.51 \pm 0.04 \mathrm{bB}$ \\
\hline 39.80 & Dihydro- $\beta$-ionone & $\begin{array}{c}(121) 999(43) 630 \\
(161) 432(123) 363 \\
(136) 363\end{array}$ & $3.09 \pm 0.21 \mathrm{aA}$ & n.d. & $3.79 \pm 0.73 \mathrm{aA}$ & $2.22 \pm 0.11 \mathrm{a}$ \\
\hline 40.87 & Hexanoic acid & $\begin{array}{l}\text { (60) } 999(73) 444 \\
\text { (41) } 422(27) 375 \\
\text { (43) } 237\end{array}$ & n.d. & $7.99 \pm 4.27$ & $2.82 \pm 0.92$ & n.d. \\
\hline 40.96 & $\alpha$-Ionone & $\begin{array}{c}(121) 999(93) 770 \\
(43) 760(136) 620 \\
(77) 333\end{array}$ & $13.92 \pm 3.11 \mathrm{aA}$ & $9.08 \pm 1.91 \mathrm{aA}$ & $25.34 \pm 1.36 \mathrm{aA}$ & $9.17 \pm 0.11 \mathrm{bA}$ \\
\hline 41.30 & Propanoic acid & $\begin{array}{l}\text { (71) } 999(56) 793 \\
(89) 722(43) 600 \\
(41) 221 \\
\end{array}$ & n.d. & n.d. & $1.54 \pm 0.03 a$ & $1.52 \pm 0.37 \mathrm{a}$ \\
\hline 41.45 & Benzyl alcohol & $\begin{array}{c}(79) 999(108) 884 \\
(77) 640(107) 616 \\
(51) 290\end{array}$ & $2.41 \pm 0.59 \mathrm{aA}$ & $1.58 \pm 0.33 \mathrm{aA}$ & $1.56 \pm 0.25 \mathrm{aA}$ & $0.35 \pm 0.07 \mathrm{bB}$ \\
\hline 41.92 & $\alpha$-Ionol & $\begin{array}{c}(95) 999(43) 656 \\
(138) 400(41) 158 \\
(96) 135\end{array}$ & $2.63 \pm 0.53 \mathrm{aA}$ & $1.73 \pm 0.52 \mathrm{aA}$ & $4.25 \pm 1.19 \mathrm{aA}$ & $1.61 \pm 0.04 \mathrm{aA}$ \\
\hline 42.07 & (E)- $\beta$-Ionone & $\begin{array}{c}(177) 999(43) 408 \\
(91) 173(135) 153 \\
(178) 134\end{array}$ & $5.38 \pm 3.83 \mathrm{aA}$ & $5.75 \pm 1.76 \mathrm{aA}$ & $12.05 \pm 4.98 \mathrm{aA}$ & $19.89 \pm 0.43 \mathrm{aA}$ \\
\hline
\end{tabular}

Rt Retention time

${ }^{1}$ Identification by comparison of mass spectra, retention times and mass spectra from the NIST Mass Spectral Library and based on rules of ion fragmentation in the mass

spectrometer.

${ }^{2}$ Calculated with the abundance of the identified compound divided to the total abundances of all the compounds \pm standard deviation.

n.d. not detected.

Means within the same crop cycle followed by different small letters are significantly different at $\mathrm{p} \leq 0.05$ (LS means test).

Means within the different crop cycle followed by different capital letters are significantly different at $\mathrm{p} \leq 0.05$ (LS means test).

\section{Volatile compounds by functional group}

Figure 1 shows the relative abundance by functional group, the C13-norisoprenoids being the most abundant group during the two crop cycles and fertilization systems. These compounds are generated by the oxidative breakdown of carotenoids (Hampel et al., 2007) and have been reported as the most abundant group in other varieties (Aprea et al., 2010; Morales et al., 2014). Unlike other authors who detected ketones as the most abundant group (Kafkas et al., 2019). This functional group was significantly affected ( $\mathrm{p} \leq 0.05$ ) by the fertilization system, presenting higher relative abundance percentages in conventionally fertilized raspberry, in both years of study. As can be seen in Table I, the percentages in the macronutrient content were higher in conventional fertilization $(\mathrm{p} \leq 0.05)$; this may have influenced these differences presented by the C-13 norisopreoids related to the fertilization system. On the other hand, other groups such as aldehydes and esters were more abundant only in the second cycle (2018) ( $\mathrm{p} \leq 0.05)$, knowing that fertilization was constant in the two crop cycles (Tables 2 and 3 ) the change in these two functional groups, more than to the fertilization 
system, it could be attributed to seasonal variation, with the 2017 cycle having greater rainfall in the months of July and August (Table 4). Ketones were influenced only by the crop cycle having a higher percentage of abundance in the first crop cycle (2017) $(\mathrm{p} \leq 0.05)$.

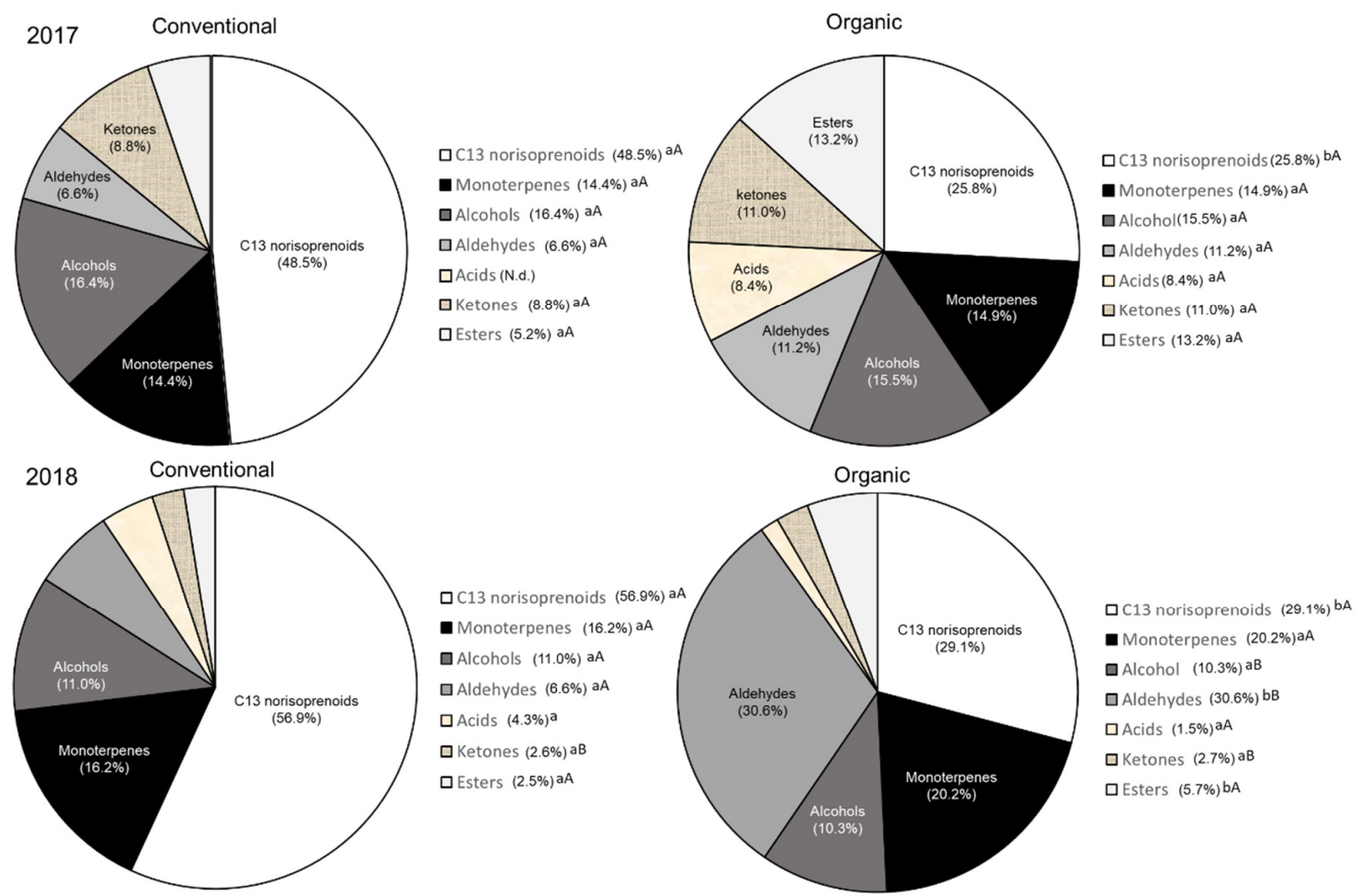

Figure 1. Volatile compounds in raspberry fruit (Rubus idaeus L.) according to chemical class

Means within the same crop cycle followed by different small letters are significantly different at $p \leq 0.05$ (LS means test)

Means within the different crop cycle followed by different capital letters are significantly different at $p \leq 0.05$ (LS means test)

Volatile impact compounds

Within the norisoprenoid group, $\alpha$ - and $\beta$-ionone are recognized as impact compounds in raspberries (Larsen et al., 1991) since $\alpha$-ionone produces fruity, floral and raspberry odour and $\beta$-ionone has an aromatic odour floral (Jaeger et al., 2013; Aprea et al., 2015). Even $\beta$-ionone is considered one of the most relevant compounds of red raspberries aroma (Larsen et al., 1991; Klesk et al., 2004). In this study, both compounds were detected as the most abundant, Kafkas et al. (2019) reporting similar results with other raspberry varieties ('Tulameen', 'Kweli' and 'Imara'). Although these compounds were significantly affected by the fertilization system, presenting a higher percentage of abundance in conventional management, this difference was not consistence by crop cycles, since $\beta$-ionone was more abundant in the 2017 cycle and, $\alpha$-ionone in the 2018 cycle $(\mathrm{p} \leq 0.05)$. Other of the identified compounds, $\beta$-phellandrene, which are characteristic of the raspberry aroma, was significantly affected by type of fertilization $(\mathrm{p} \leq 0.05)$. This belongs to the terpenes group (Aprea $e$ al., 2015 ) and it's responsible for floral and herbaceous aromas (Boylston, 2010). Meanwhile, acetoin, belonging to the ketone group, was mainly affected by the cycle of cultivation $(\mathrm{p} \leq 0.05)$.

On the other hand, some compounds considered to have an impact in raspberries such as linalool, from the terpenes group, which provides floral essence in fruits (El Hadi et al., 2013) and $\alpha$-ionol (C-13 norisoprenoid) that gives sweet aroma to lemon and hot tea (Larsen et al., 1991; Robertson et al., 1995), were not significantly influenced by fertilization systems or seasonal variation ( $\mathrm{p} \geq 0.05)$ (Table 5). 


\section{Conclusions}

The effect of the crop cycle as well as the fertilizer system (organic and conventional) of the cv. 'Heritage' raspberry, modified the qualitative profile of volatile compounds related to flavour. The raspberry grown under conventional fertilization showed a greater abundance of volatile compounds, especially from the C-13 norisoprenoid group. While ketones had less abundance in the second crop cycle. It is advisable to conduct studies that establish the relationship of the effect of nutrients absorbed by plants from organic and conventional fertilizers, as well as investigate whether the changes that occur modify the aromatic perception of these fruits by consumers.

\section{Acknowledgements}

This research received no specific grant from any funding agency in the public, commercial, or not-forprofit sectors.

\section{Conflict of Interests}

The authors declare that there are no conflicts of interest related to this article.

\section{References}

Aprea E, Biasioli F, Gasperi F (2015). Volatile compounds of raspberry fruit: from analytical methods to biological role and sensory impact. Molecules 20(2):2445-2474. http://dx.doi.org/10.3390/molecules20022445

Aprea E, Biasioli F, Carlin S, Endrizzi I, Gasperi F (2009). Investigation of volatile compounds in two raspberry cultivars by two headspace techniques: solid-phase microextraction/gas chromatography-mass spectrometry (SPME/GCMS) and proton-transfer reaction-mass spectrometry (PTR-MS). Journal of Agricultural and Food Chemistry 57(10):4011-4018. https://doi.org/10.1021/jf803998c

Aprea E, Carlin S, Giongo L, Grisenti M, Gasperi F (2010). Characterization of 14 raspberry cultivars by solid-phase microextraction and relationship with gray mold susceptibility. Journal of Agricultural and Food Chemistry 58(2):1100-1105. http://dx.doi.org/10.1021/jf902603f

Benbrook C (2009). The impacts of yield on nutritional quality: lessons from organic farming. HortScience 44(1):12-14. bttp://dx.doi.org/10.21273/HORTSCI.44.1.12

Boylston T (2010). Temperate fruit juice flavour. In: Hui YE (Ed). Handbook of Fruit and Vegetable Flavors. John Wiley \& Sons Inc., Hoboken pp 451-562.

El Hadi M, Zhang F, Wu F, Zhou C, Tao J (2013). Advances in fruit aroma volatile research. Molecules 18(7):8200-8229. http://dx.doi.org/10.3390/molecules 18078200

Esitken A, Ercisli S, Karlidag H, Sahin F (2005). Potential use of plant growth promoting rhizobacteria (PGPR) in organic apricot production. In: Proceedings of the International Scientific Conference of Environmentally Friendly Fruit Growing, Tartu-Estonia, pp 90-97.

Forney C (2001). Horticultural and other factors affecting aroma volatile composition of small fruit. HortTechnology 11(4):529-538. http://dx.doi.org/10.21273/HORTTECH.11.4.529

Frias-Moreno M, Olivas-Orozco G, Gonzalez-Aguilar G, Benitez-Enriquez Y, Paredes-Alonso A, Jacobo-Cuellar J, ... Parra-Quezada R (2019). Yield, quality and phytochemicals of organic and conventional raspberry cultivated in Chihuahua, Mexico. Notulae Botanicae Horti Agrobotanici Cluj-Napoca 47(2):522-530. http://dx.doi.org/10.15835/nbha47211385

Gomiero T (2017). Food quality assessment in organic vs. conventional agricultural produce: findings and issues. Applied Soil Ecology 30(40):1-15. http://dx.doi.org/10.1016/j.apsoil.2017.10.014 
Guzman-Soria E, García-Mata R, Muratalla-Lúa A, García-Delgado G, Mora-Flores J (2004). Análisis de precios de la frambuesa roja (Rubus idaeus L.) producida en el Valle de Bravo, México [Price analysis of the red raspberry (Rubus idaeus L.) produced in the Valle de Bravo, Mexico]. Revista Agrociencia 38(5):565-571.

Hampel D, Swatski A, Mosandl A, Wust M (2007). Biosynthesis of monoterpenes and norisoprenoids in raspberry fruits (Rubus idaeus L.): the role of cytosolic mevalonate and plastidial methylerythritol phosphate pathway. Journal of Agricultural and Food Chemistry 55(22):9296-9304. https://doi.org/10.1021/jf071311x

Jaeger S, McRae J, Bava C, Beresford M, Hunter D, Ji Y, ... Gamble J (2013). Mendelian train for olfactory sensitivity affects odor experience and food selection. Current Biology 23(16):1601-1605. https://doi.org/10.1016/j.cub.2013.07.030

Kafkas E, Sönmez DA, Oguz İB, Attar ŞH (2019). Comparison of volatiles in various raspberry fruits by $\mathrm{HS} / \mathrm{SPME} / \mathrm{GC} / \mathrm{MS}$ techniques. Acta Horticulturae 1265:293-300. https://doi.org/10.17660/ActaHortic.2019.1265.41

Klesk K, Qian M, Martin R (2004). Aroma extract dilution analysis of cv. 'Meeker' (Rubus idaeus L.) red raspberries from Oregon and Washington. Journal of Agricultural and Food Chemistry 52:5155-5161. https://doi.org/10.1021/jf0498721

Lairon L (2010). Nutritional quality and safety of organic food. A review. Agronomy for Sustainable Development 30(1):33-41. http://dx.doi.org/10.1051/agro/2009019

Larsen M, Poll L, Callesen O, Lewis M (1991). Relations between the content of aroma compounds and the sensory evaluation of 10 raspberry varieties (Rubus idaeus L). Acta Agriculture Scandinavica 41(4):447-457. https://doi.org/10.1080/00015129109439927

Morales M, Callejón R, Ubeda C, Guerreiro A, Gago C, Miguel M, Antunes M (2014). Effect of storage time at low temperatures on the volatile compound composition of Sevillana and Maravilla raspberries. Postharvest Biology and Technology 96:128-134. https://doi.org/10.1016/j.postharvbio.2014.05.013

Parra-Quezada RA, Ramírez-Legarreta MR, Jacobo-Cuellar JL, Arreola-Ávila JG (2008). Fenología de la frambuesa roja Autumn Bliss en Guerrero, Chihuahua, México [Phenology of the red raspberry Autumn Bliss in Guerrero, Chihuahua, Mexico]. Revista Chapingo Serie Horticultura 14(1):91-96.

Peña-Varela G, Salinas-Moreno Y, Ríos-Sánchez R (2006). Contenido de antocianinas totales y actividad antioxidante en frutos de frambuesa (Rubus idaeus L.) con diferente grado de maduración [Total anthocyanin content and antioxidant activity in raspberry fruits (Rubus idaeus L.) with different ripeness]. Revista Chapingo Serie Horticultura 12(2):159-163.

Raffo A, Baiamonte I, Bucci R, D'Aloise A, Kelderer M, Matteazzi A, ... Peparaio M (2014). Effects of different organic and conventional fertilisers on flavour related quality attributes of cv. 'Golden Delicious' apples. LWT-Food Science and Technology 59(2):964-972. https://doi.org/10.1016/j.lwt.2014.06.045

Rao A, Snyder D (2010). Raspberries and Human Health: A Review. Journal of Agricultural and Food Chemistry 58(7):3871-3883. https://doi.org/10.1021/jf903484g

Robertson G, Griffiths D, Woodford J, Birch A (1995). Composition of volatiles released by the flowers and fruits of the red raspberry (Rubus idaeus) cultivar Glen Prosen. Phytochemistry 38(5):1175-1179. https://doi.org/10.1016/0031-9422(94)00782-O

Servicio de información agroalimentaria y pesquera (2018). Retrieved 2018 December 13 from https://nube.siap.gob.mx/cierreagricolal

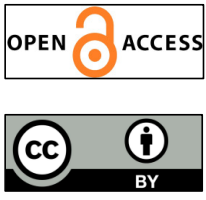

The journal offers free, immediate, and unrestricted access to peer-reviewed research and scholarly work. Users are allowed to read, download, copy, distribute, print, search, or link to the full texts of the articles, or use them for any other lawful purpose, without asking prior permission from the publisher or the author.

License - Articles published in Notulae Botanicae Horti Agrobotanici Cluj-Napoca are Open-Access, distributed under the terms and conditions of the Creative Commons Attribution (CC BY 4.0) License. (C) Articles by the authors; UASVM, Cluj-Napoca, Romania. The journal allows the author(s) to hold the copyright/to retain publishing rights without restriction. 